\title{
The Perspective of Efl Teachers On the Use of Communicative Language Teaching Clt in English Classes in Erbil City
}

\section{Sangar Lateef Omer}

Department of English, College of Languages, Salahaddin University, Erbil, KR-Iraq Sangaromar84@gmail.com

\section{ARTICLE INFO}

\section{Article History:}

Received: 5/6/2020

Accepted: 8/7/2020

Published: Spring 2020

\section{Keywords:}

Communicative

Language Teaching

CLT, Teachers' views,

Erbil city, foreign language, modification

Doi:

10.25212/Ifu.qzj.5.2.36
ABSTRACT

There are increasing demand in schools in Erbil city to bring a change to the current ELT teachings, and the academic literature has shown that Communicative Language Teaching English in the classrooms is positively associated with school leaders' effectiveness at implementing reforms. The purpose of this study is to survey the communicative language teaching CLT in English language teaching classrooms as a foreign language in Erbil city, to bring about change and innovation within this Middle Eastern educational system, and to investigate teachers' and principals' overall acceptance of this type of leadership in this country. The methods used to realize in this study involves an initial questionnaire and a detailed follow-up to 27 teachers and principal's interviews conducted by the researcher. The findings indicate that principals believe they are practicing high levels of Communicative Language Teaching English in the classrooms, but the majority of the teachers have an iconoclastic view with that assessment. This trend emerges from all the components of the Communicative Language Teaching English in the classrooms model that was utilized in the 1189 
study: challenging the process, inspiring a shared vision, enabling others to act, modeling the way, and encouraging the heart. This realization suggests that Communicative Language Teaching English in the classrooms can still be a success in Erbil city, but modification of that model is suggested.

\section{INTRODUCTION}

Communicative Language Teaching (CLT) was viewed as progressive since it set a fundamental accentuation on correspondence in dialect learning classrooms. Being basically English as a second language (ESL) strategy, it quickly picked up a boundless acknowledgement in the Western nations. Emulating the rise of CLT in English-talking nations, it started to spread everywhere throughout the world. Regardless of the clear notoriety of CLT in the last thirty years or so, there have been contradicting perspectives on the suitability, and in addition to the attainability of executing CLT in EFL connections. Some English dialect educating (ELT) researchers have accentuated the centrality of the neighborhood needs and the states of the specific EFL settings, and the profits of the customary techniques for dialect instructing (Bax, 2003, \& Ansarey, 2012). After more than ten years of exchange, very little has changed in English classrooms in Erbil city with respect to moving towards a more open methodology. In spite of the fact that the current English showing educational module forced by the MOHE\& MOE are plainly focused around the CLT strategy, and a student focused methodology has been formally embraced, conventional systems, for example, the Grammar-interpretation technique still overwhelm the EFL classroom in Erbil city.

\section{Methodology}

\subsection{Research Model}




\section{QALAAI ZANISTSCIENTIFIC JOURNAL \\ A Scientific Quarterly Refereed Journal Issued by Lebanese French University - Erbil, Kurdistan, Iraq \\ Vol. (5), No (2), Spring 2020 \\ ISSN 2518-6566 (Online) - ISSN 2518-6558 (Print)}

According to the social sciences, the results and reality gathered in a natural context analysis are more meaningful than the results found in an artificial context analysis. Qualitative study tries to identify and understand human behaviors within natural context. It rejects analyses of the artificial context that is because of the fact that the observed changing behaviors cannot be accepted as 'natural' in artificial environment since they do not reflect the true reality (Keskin 2014). In this qualitative study, the main element is to gather the detailed views from the participants. This data collection technique does not only enable the researcher to give detailed information about the views, and experiences of the participants who change constantly within a naturally changing environment, but also it is a good alternative to quantitative study.

\section{This study aims to find answers to the following research questions:}

1. What problems are inherent in English teaching in Erbil city?

2. How can communicative language teaching CLT contribute to English teaching in Erbil city?

3. How feasible is communicative language teaching in Erbil city?

4. What are the difficulties and challenges that EFL teachers face in using CLT in their English classrooms in Erbil city?

\subsection{Participants}

The participants for this study were totally twenty-seven from Erbil city where English is the second language ESL, the break down was like ( 12 females and 15 male) at primary, intermediate, preparatory and university levels. These 15 participants were involved in the survey while four principals and 12 teachers participated in the semi-structured interviews.

\begin{tabular}{|c|c|c|}
\hline \multicolumn{3}{|c|}{ Table ( 1 ) : Participant's Survey } \\
\hline Gender & Frequency & Percentage \\
\hline Female & 12 & $44.44 \%$ \\
\hline Male & 15 & $55.55 \%$ \\
\hline
\end{tabular}

Table (1) showing the percentage of the survey. 


\section{QALAAI ZANISTSCIENTIFIC JOURNAL}

A Scientific Quarterly Refereed Journal Issued by Lebanese French University - Erbil, Kurdistan, Iraq

Vol. (5), No (2), Spring 2020

ISSN 2518-6566 (Online) - ISSN 2518-6558 (Print)

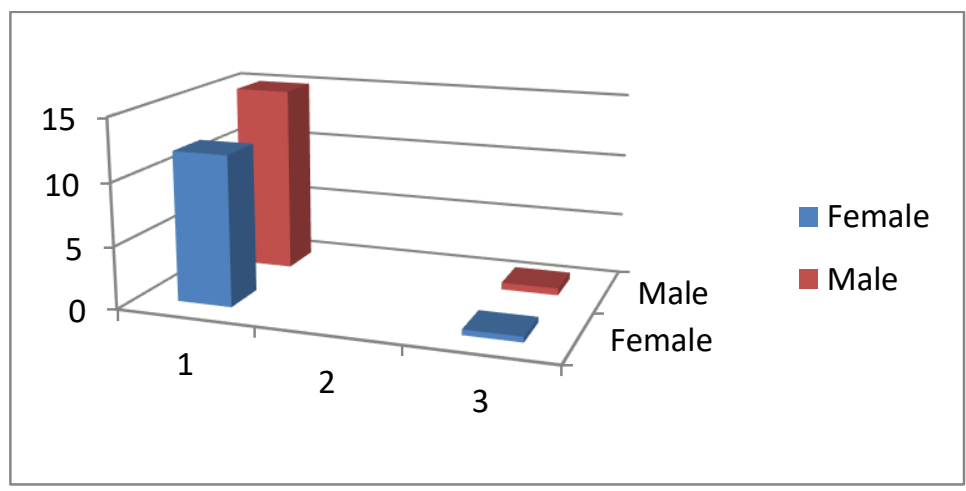

Figure 3.2 distribution of participants' year of experience

Figure 3.1: Participant's distribution according to their number

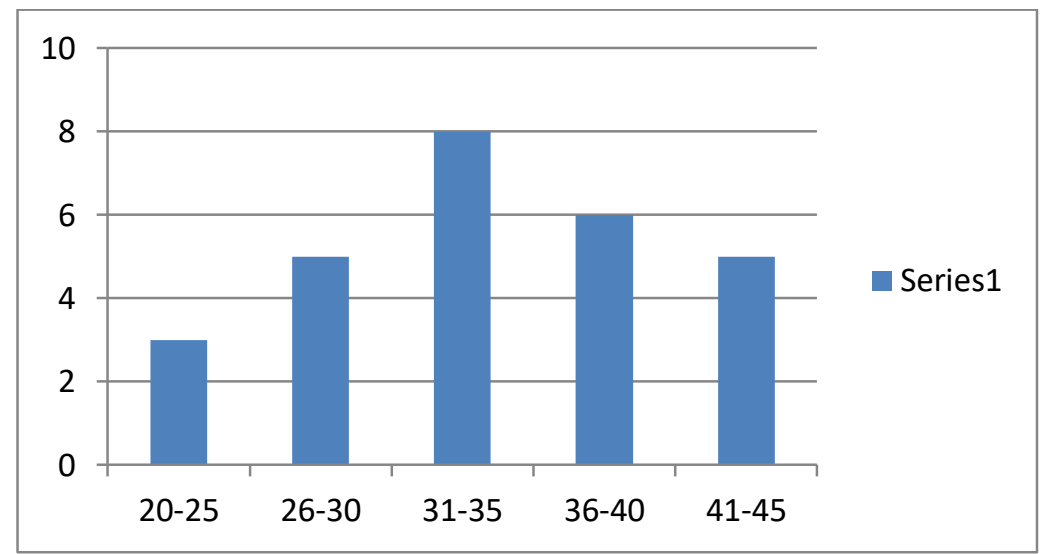

Figure 3.2: Distribution of the participants according to their ages

\subsection{Communication According to the Ability}

Whether CLT should be considered an approach or a methodology is more an abstract debate and this research wants to deal with its more practical aspects. In fact, it is those very elements, and the name itself, which have been used to challenge the future relevance of CLT. First of all, the label implies a focus on communication and some might argue that this method can't be employed genuinely with low levels as there is no authentic communication, due to a limited vocabulary and restricted range of functions. With the emphasis on communication, there is also the implication that communication exchanges 


\section{QALAAI ZANISTSCIENTIFIC JOURNAL \\ A Scientific Quarterly Refereed Journal Issued by Lebanese French University - Erbil, Kurdistan, Iraq \\ Vol. (5), No (2), Spring 2020 \\ ISSN 2518-6566 (Online) - ISSN 2518-6558 (Print)}

should be authentic and meaningful; detractors claim that the artificial nature of classroom-based (i.e. teacher - created) interactions makes CLT an oxymoron. Nevertheless, a proficient teacher will provide a context so that class interactions are realistic and meaningful but with the support needed to assist students to generate the target language.

\subsection{Accuracy as well as Fluency}

This focus on accuracy versus fluency is one of the issues not often considered in a discussion of CLT. While CLT implies the lessons are more student-centered, this does not mean they are un-structured. The teacher does have a very important role in the process that is, setting up activities so that communication actually happens. There is a lot of preparation; accuracy practice is the bridge to a fluency activity. By implication, CLT involves equipping students with vocabulary, structures and functions, as well as strategies, to enable them to interact successfully (Doman et al., 2005).

\subsection{Motivation and Promoting Learning}

This returns us to the consideration of who we are teaching, and why are our students aiming to learn or acquire English? Do they need to know lexical items and linguistic rules as a means of passing an exam, or do they want to be able to interact in English? It is timely to review an early definition of CLT. CLT is basically about promoting learning. Furthermore, one of the constant discussions in Erbil city teacher training groups was how to motivate students. This suggests that the focus on passing the exam was not always enough. Motivation relates to engaging students but also includes confidence building. If there is a climate of trust and support in the classroom, then students are more likely to contribute. One way of developing this is to allow pair-checking of answers before open-class checking or small groups discussion etc. Doman et al., (2005) suggests that "The need for ongoing negotiation during interaction increases the learners' overt participation..."

\subsection{Data Collection Procedure}

The researcher conducted the interviews and recorded the answers of the respondents since the study aims to reflect the views, thoughts and feelings of the participants as accurately as possible. It is also crucial to mention the fact that the respondents were not given the opportunity to read through the 


\section{QALAAI ZANISTSCIENTIFIC JOURNAL \\ A Scientific Quarterly Refereed Journal Issued by Lebanese French University - Erbil, Kurdistan, Iraq \\ Vol. (5), No (2), Spring 2020 \\ ISSN 2518-6566 (Online) - ISSN 2518-6558 (Print)}

questions before the interview. In case of misunderstanding, the researcher reformulates or explains the questions again when necessary. In this study, the content analyses typical of those used with qualitative data were used.

\subsection{Sources of Information}

In order to get a comprehensive picture of the target culture from many angles, we need to present our students with different kinds of information. The list below shows some possible sources of information which can be used as materials for teaching culture. By using a combination of visual, audio and tactile materials, we are also likely to succeed in addressing the different learning styles of our students.
1. Video
2. CDs
3. Reading
4. Internet
5. Stories
6. Students Own Information
7. Songs
8. Newspaper
9 Realia
10. Fieldwork
11. Interviews
12. Guest Speakers
13. Anecdotes
14. Souvenirs
15.
16. Surveys
Photographs

17. Illustration 18. Literature

\subsection{Activities used in CLT Classrooms}

\subsubsection{Jigsaw Activity}

The preference of jigsaw exercises is that students must rely on one another for their data, so they must interface to fulfill a given assignment. The goal is that students read the content, hear the content, ace new vocabulary, reword, and associate at all phases of the action. The depiction underneath is for a talk class, yet few teachers in Erbil city have likewise utilized it with basic areas of parts in books as a warm-up movement for long messages. The objective is to choose segments that:

a. Have quite recently enough data to stimulate the student's enthusiasm for whatever remains of the story,

b. Contain essential data not found in different areas. Also, 


\section{QALAAI ZANISTSCIENTIFIC JOURNAL \\ A Scientific Quarterly Refereed Journal Issued by Lebanese French University - Erbil, Kurdistan, Iraq \\ Vol. (5), No (2), Spring 2020 \\ ISSN 2518-6566 (Online) - ISSN 2518-6558 (Print)}

1. Dividing up the article up as per these criteria.

2. In this way, the undertaking of perusing turns into an intelligent critical thinking movement.

3. Preparing a freebee sheet with guidelines for doing the action.

4. Labeling every sheet contrastingly as a method for verifying students in the first gathering action have the same gift.

The example mentioned below used by some teachers:

(Total Time: 35-60 minutes, depending on student level and the difficulty of the article)

First Group Activity (Time: 10-20 minutes)

1. Pivide the clgss into 3 or 4 groups, depending on how many sections you have selected from the newspaper article.

2. Have the students read the instructions carefully, noting the rules.

3. As a group, hqve the stydents yrite out two questions they would like to ask others to gain a better understanding of the entire article.

\subsubsection{Information-Gap- Filling}

In this action, students should be working in sets. One student will have the data that other accomplice does not have and the accomplices will impart their data. Additionally, every accomplice assumes an imperative part on the grounds that the undertaking can't be finished if the accomplices don't give the data the others require. These exercises are successful in light of the fact that everyone has the chance to talk broadly in the target dialect. As mentioned in this thesis, a question is asked from some teachers in Erbil city about the information-gap activity, and their answers were almost similar as they have two parts. The first part is called preparation, and the second part called procedure:

Preparation:

1. Collect personal information from teachers that the students know.

2. Select 5 pieces of information about each teacher. 


\section{QALAAI ZANISTSCIENTIFIC JOURNAL \\ A Scientific Quarterly Refereed Journal Issued by Lebanese French University - Erbil, Kurdistan, Iraq \\ Vol. (5), No (2), Spring 2020 \\ ISSN 2518-6566 (Online) - ISSN 2518-6558 (Print)}

3. Write the selected information on the teacher information sheet.

4. Paste the teacher information sheet to a piece of colored paper.

5. Repeat Steps 2-4 for each teacher.

6. Print a copy of the student worksheet for each student.

Procedure:

1. Divide the students into small groups and distribute the worksheets.

2. Put the teacher information sheets face down at the front of the classroom.

3. A member from each group is given one minute to memorize the information.

4. The members return to their groups and dictate the information.

5. Steps $4-5$ are repeated until each member has had two turns.

6. As a class, the sentences about each teacher are checked.

7. The groups are given a few minutes to decide the identities of the teachers.

8. As a class, check the identities of the teachers.

\subsection{The Definition and Advantages of CLT}

It is necessary to define the term communicative for the conceptualization of the communication from a general and language teaching point of view in the communicative of the study. The "New Oxford American Dictionary third edition" (2011) of the English Language gives the definition of communicative as:

"Method of teaching a foreign language which aims to develop communicative competence, as opposed to simple knowledge of language"

The comparison of communicative versus whole language perceptions by total ESL teacher group showed that, in general, teachers' perceptions about the communicative approach were greater than their perceptions about the whole language approach. They showed distinctly positive trends with significantly higher ratings when compared to the whole language approach except for the following seven items with no significant differences:

1. Integration of language arts,

2. Content learning, 


\section{QALAAI ZANISTSCIENTIFIC JOURNAL \\ A Scientific Quarterly Refereed Journal Issued by Lebanese French University - Erbil, Kurdistan, Iraq \\ Vol. (5), No (2), Spring 2020 \\ ISSN 2518-6566 (Online) - ISSN 2518-6558 (Print)}

3. Reading achievement,

4. Portfolio assessment,

5. Paper and pencil tests,

6. Student achievement of English literacy, and

7. Student everyday writing.

As is often true of Erbil city families, the first generation only learns the most basic vocabulary and grammar but the children, if given the chance, will learn to function better in the new language than in their mother tongue. These children traveled from place to place nine months out of a year, so received very little formal education in the governmental school system, where the lesson is only $40 \mathrm{~min}$ and only one lesson in the day. Because of this they had very few skills in reading or writing.

Where, the following question to some teachers was asked:

What problems are inherent in English Teaching in Erbil city? And the answer was:

"- Lack of lab.

- Crowd classes.

- Insufficiency of practice

\subsection{Analysis of the Methodology and Syllabus}

In the wake of distinguishing the learning circumstance, we should start to consider what kind of procedure may be suitable. Since the advent of CLT and the belief that language is best learned when it is being used to communicative messages. Research findings in the field of general education into teachers' actual classroom practices and in second language acquisition have led to claims that the task syllabus has a richer potential for promoting successful second language learning than do other syllabus types (e.g. structural, notional/functional, situational, topical). In fact, one of the most important ideas to emerge from these studies is that where one uses language is less relevant for language learning than what one uses it for, e.g. task.

Despite the current emphasis on TBLT in the research literature, there are as yet few genuinely task-based textbooks in the market (although there are a number of task-based teacher resource books, e.g. Nunan's Altas, 1995 series) 


\section{QALAAI ZANISTSCIENTIFIC JOURNAL \\ A Scientific Quarterly Refereed Journal Issued by Lebanese French University - Erbil, Kurdistan, Iraq \\ Vol. (5), No (2), Spring 2020 \\ ISSN 2518-6566 (Online) - ISSN 2518-6558 (Print)}

claim to be task-based, but are still based on an underlying grammatical syllabus. Furthermore, teachers are frequently required to use a textbook mandated by the institution for which they teach. Therefore, the only alternative open to many teachers who wish to use a task-based approach is to adapt the materials found in traditional textbooks to fit the principles and procedures of TBLT.

\subsection{Ethics}

First of all, a proposal proposition was composed to the administrator individuals from the Institute of Social Sciences including the title of the Thesis, the point of the study, and the hugeness of the study. A short outline of the technique and dynamic segments of the study were likewise included all along with the sign of the Supervisor and the head of office to give the administrator individuals from the Institute of Social Sciences with concise data about the study.

For the greetings

- Hello.

- Good morning (class/everyone).

- Good afternoon (class/everyone).

- That's all for today.

- Goodbye.

- See you tomorrow/next week/Friday.

For the directions

- Stand up.

- Sit down. / Be seated.

- Open your (text) books/notebooks (to page /chapter /section ).

- Turn to page .

- Come to the blackboard/front.

- Translate this into English/L1.

Arrangements of statements like these appear to be coursing all around for good reason. Students need to take in these sorts of statements on the off chance that they are to convey in English in class.

- Excuse me? 
- I didn't hear you.

- Just a minute, please.

- I don't understand. (Huh?)

- Idon't know.

- How do you say this word?

\subsection{Summary}

A hundred meetings, the best textbooks, creative teaching materials, even native speakers visiting the classroom aren't going to "give" ESL students English communicative ability. Only by using English communicatively between the teacher and classmates, the students will develop the ability to speak English. Taken for instance, if the teacher decides to teach some grammar points in English and not found in L1, it will be much difficult for the students (and for the teacher), but at the same time they will probably remember the ideas better. This is because of their native language is not the English as the case in Erbil city, and they actually have to listen and think about what he is saying. Thus, not only will their (and the teacher) communicative ability improve, but so will their test scores. Conversely, the students won't attempt to communicate in English if the teacher is unwilling to do so by him. The teacher is not just teaching spelling, vocabulary, and grammar in class; the teacher is indirectly teaching his students the value of communicating in English. If does not show his students by using English that he thinks it's important, they won't think it is. If students are taught primarily in their native language, they may learn how to read, they may learn how to write, they may learn how to translate, but they aren't very likely to learn how to speak or even learn the English language as a second language for them.

\section{Results and Discussion}

\subsection{Background Information of the Teachers Using Originality of CLT English in Classrooms in Erbil city}

The open methodology could be said to be the result of teachers and etymologists who had developed disappointed with the audio-lingual and linguistic used interpreting systems for remote dialect guideline. They felt that 
students were not adapting enough practical, entire dialect. Within the social psychology of identity, a person's self-image is seen to have two components: namely, personal identity and social identity. One's native dialect or language permeates one's personal identity; therefore, it is essential in every individual's advancement, further shaped by the national education process. It is in the development of a personal sense of language that we shape our personality and learn to explore ourselves.

\subsection{Interview Question 1:}

\section{What problems are inherent in English Teaching in Erbil city?}

Teacher 1: Teaching English is not an easy task in Erbil city, of course, there are problems in this regard since it is a foreign language. The most difficult is pronunciation as students are suffering lots of times in learning in this field. Another set of answers for the same question

Teacher 2: There are some problems in teaching here, For example, A/ Having terrible pronunciation by Kurdish teachers who teach students. B/ Not having enough Kurdish teachers for teaching students English Academic Writing.

Teacher 3: There are many problems we can divide into physical and psychological: Physical problems include the class environment, equipment, materials, testing materials, number of students, time management, etc. Psychological: Student anxiety before and after the exam and in daily life, threatening and scaring students by teachers, relations among teachers and headmasters, studying for marks etc.

Teacher 4: We don't use English for speaking; in Erbil city have many problems in English teaching. The origins of communicative language teaching are to be found in the changes in the British language teaching, but now we talked in American language (dialects) teaching because it changes the methods of learning and teaching English.

Teacher 5: First English language isn't rife in Erbil city and its lingo, second there isn't an English program in T.V for teaching English and there isn't a good program in education finally we haven't a professional English teacher in Erbil city. 


\section{QALAAI ZANISTSCIENTIFIC JOURNAL}

A Scientific Quarterly Refereed Journal Issued by Lebanese French University - Erbil, Kurdistan, Iraq

Vol. (5), No (2), Spring 2020

ISSN 2518-6566 (Online) - ISSN 2518-6558 (Print)

Teacher 6:

- Lack of proper resources in English

- Lack of proper classroom and labs (e.g.: Sound Lab)

- Students are not motivated

\subsection{Interview Question 2}

How can communicative language teaching contribute to English teaching in Erbil city?

Teacher 1: Absolutely CLT contribute in teaching language in Erbil city because it will help teachers to save time and help students to learn English sooner. CLT will help teachers to make students learns Grammar spelling ...etc. in a very short time.

Teacher 2: CLT can be used to have new changes in teaching methods since it is one of the dominant methods. Although it is new in Erbil city for both teachers and students, it is a good attempt to use it. It helps the teachers to gain the goals easily and learners learn more. CLT doesn't only focus on grammar only; it prefers an argumentative and a communicative class.

Teacher 3: Language is acquired through communication.

- CLT allows learners to use the target language in meaningful context.

- Increase of fluency in the target language. This enables the learners to be more confident when interacting with other people and they also enjoy talking more.

Teacher 4: We need to make a bridge between the nations and states that are speaking English. It can be open international institute specialist for teaching and learning English.

Teacher 5: We need a special or particular English periodic or course in Erbil city and more application in life and use more words in conversation and we need more programs in T.V and finally more diffusion or prevalent English story and book and magazine in Erbil city.

Teacher 6: It could restore motivation among students and create a more enjoyable atmosphere in the classroom.

\subsection{Interview Question 3}




\section{QALAAI ZANISTSCIENTIFIC JOURNAL \\ A Scientific Quarterly Refereed Journal Issued by Lebanese French University - Erbil, Kurdistan, Iraq \\ Vol. (5), No (2), Spring 2020 \\ ISSN 2518-6566 (Online) - ISSN 2518-6558 (Print)}

How feasible is communicative language teaching in Erbil city?

Teacher 1: CLT are feasible here if the schools, classrooms, time ......etc. are suitable. In other words, we can make use of CLT if there are good buildings, sound labs...etc. in this way we can get benefit from CLT.

Teacher 2: Although a specific group of teachers want applies this method, we should remember that our school environments are not ready to it. It is uneasy to follow it. There are many obstacles as mentioned before.

Teacher 3: It is absolutely feasible because everyone knows that English is an international language.

Teacher 4: CLT still is a new approach teaching in Erbil city, so it needed more knowledge and enhancement.

Teacher 5: There are many ways:

a. It sponsored international conferences on language teaching.

b. Published books about language teaching.

c. Dialogues, if used, center on communicative functions and are not normally memorized.

d. Language learning is learning to communicate.

Teacher 6: We need a special course for teachers and good program in education and special English class in school.

- As far as I am concerned, communicative language teaching the best effective way ahead for teaching English in Erbil city.

\subsection{Interview Question 4}

What are the difficulties and challenges that Kurdish EFL teachers face in using CLT in their English classroom?

Teacher 1: There are many difficulties; the most important ones are students' levels, number of students in the class, the curriculum. These difficulties can be overcome if we did our best to make changes in the problems that have just mentioned above.

Teacher 2: A/ Not having a good scientific laboratory for teaching English phonetic and phonology. B/ Not having an electronic library. Not having enough 
English sources for students to study. C/ Having a lot of students in the class, which it may make teachers could not control the class during teaching.

Teacher 3: Initially, many students in Erbil city's school may not be convinced of the benefits of CLT group reading or writing. This may be due to the fact that some students prefer working individually rather than in groups or pairs.

\section{Teacher 4:}

- Use different materials.

- Do different tasks with the same materials.

- Use the students: some teachers adopt a strategy of peer help and teaching so that better students can help weaker ones.

\section{Teacher 5:}

a. More students in the classroom.

$b$. The teachers have more lessons.

c. Few or insufficient book for pupil.

$d$. There isn't equipment in the school or classroom for teaching.

\section{Teacher 6:}

- Lack of proper resources

- The large number of students per classroom

- Student motivation

First Research Question: What problems are inherent in English Teaching in Erbil city?

Where, most of the teachers gave answers, and their answers were almost similar as: "One of the problems is that, English is studied just for passing an exam not for learning the wrong idea of Kurdish students is to pass an exam but language is taught to be able to communicate with it".

Second Research Question: How can communicative language teaching contribute to English teaching in Erbil city?

Also the answer was: "CLT can contribute by changing the direction from writing to speaking and familiarizing the students that language is for communication". 
Third Research Question: How feasible is communicative language teaching in Erbil city?

Where the answer was: "It is not applicable because the majority of the teachers are not familiar with CLT. They might say we follow CLT but based on my experience, and some research, I found that they approach they adopt in Erbil city is not CLT. The assessment of the curriculum is not".

Fourth Research Question: What are the difficulties and challenges that Kurdish EFL teachers face in using CLT in their English classroom?

The answer was: "The difficulties are the assessment of the students in the final exam because the assessment is just on the writing English and its grammar. However, there is no assessment on speaking.

The above questions were done as a complete packet of the questions sent to the teachers in different schools in Erbil city, and the answers are almost similar. Applied linguists and philosophers addressed another fundamental dimension of language: the functional and communicative potential of language. The speech act theory showed that we do something when we speak a language. We use language (Halliday 1993)

- To get things,

- To control behavior,

- To create interaction with others,

- To express personal feelings,

- To learn,

- To create a world of imagination,

- To communicate information.

One of the most important questions asked from the teachers in the schools of Erbil city, which is

"How to teach effective English in the classrooms according to the communicative language teaching method?"

Answer:

1. Form the class in gatherings of four. 


\section{QALAAI ZANISTSCIENTIFIC JOURNAL \\ A Scientific Quarterly Refereed Journal Issued by Lebanese French University - Erbil, Kurdistan, Iraq \\ Vol. (5), No (2), Spring 2020 \\ ISSN 2518-6566 (Online) - ISSN 2518-6558 (Print)}

2. Distribute duplicates of Story $A$ to two individuals from each one gathering while disperse duplicates of Story $B$ to the next two individuals.

3. Collect the duplicates of the stories.

4. Rearrange the groupings in the entire class, banding together learners who read Story $A$ with the individuals who read Story $B$ however who are not in their unique gatherings.

Another question was asked from the teachers was:

"How can you make your students effective in the English classroom?"

And the answer was common in most of the teachers as:

By applying these techniques:

1. Speak gradually. Your students will have of an opportunity time to comprehend what you're stating and you'll have of a chance time to pick your words.

2. By keeping up eye get in touch while speaking.

3. Welcome students' inquiries on any subject.

4. Write a short blueprint of your presentation on the board ahead of time.

These questions were asked to the private colleges in Erbil city, and some questions asked from teachers in the governmental schools, these questions are as follows:

"How can communicative language teaching contribute to English teaching in Erbil city?"

And the answer was almost common between the teachers as:

"Communicative language can enhance their speaking skill.

- It can make the Kurdish students fluent.

- It can introduce them new vocabularies via those they communicate with.

- It can help them to look for new word, phrases, and expressions to deliver their message more properly.

"How feasible is communicative language teaching in Erbil city?"

The answer was

"That really depends on the stage, subject and place, but generally it is feasible. 


\section{QALAAI ZANISTSCIENTIFIC JOURNAL \\ A Scientific Quarterly Refereed Journal Issued by Lebanese French University - Erbil, Kurdistan, Iraq \\ Vol. (5), No (2), Spring 2020 \\ ISSN 2518-6566 (Online) - ISSN 2518-6558 (Print)}

And another question was

What are the difficulties and challenges that Kurdish EFL teachers face in using CLT in their English classroom?

Where the answer was

"Most of the students are very eager to learn English, but they are not in interested in communicating in English, this is a paradoxical difficulty.

- Large-class size.

- Inappropriateness of topics in the curriculum.

These can be overcome to large and remarkable extent if:

- Students are told from the first session that they have to communicate in English.

- The number of students has to be decreased.

One of the teachers, when he got the question about the communicative language teaching English in the classrooms especially in Erbil city for the students as a second language, his answer was to utilize creativity such as:

"Using the Communicative Language Teaching Method is a path for both teacher and students to get the most out of the classroom experience. Use your own imagination to make exercises and activities that would somehow have your students either groaning or wheezing. This strategy likewise ought to encourage a safe learning environment where students are agreeable.

\subsection{Communicative Competence}

Mullen, Greenlee and Bruner, (2005), Savignon and Wang (2003) portrayed communicative competence as having the following elements:

1. Informative capability is an element as opposed to a static idea. It relies on upon the transaction of significance between two or more individuals who offer to some degree the same typical framework.

2. Open ability applies to both composed and talked dialect, and an excess of other typical frameworks.

3. Open ability is connection particular. Correspondence happens in a boundless assortment of circumstances, and accomplishment in a specific part relies on upon one's comprehension of the connection and on related knowledge of a comparable kind. 


\section{QALAAI ZANISTSCIENTIFIC JOURNAL \\ A Scientific Quarterly Refereed Journal Issued by Lebanese French University - Erbil, Kurdistan, Iraq \\ Vol. (5), No (2), Spring 2020 \\ ISSN 2518-6566 (Online) - ISSN 2518-6558 (Print)}

4. There is a hypothetical distinction in the middle of ability and execution. Capability is characterized as an assumed fundamental capacity and execution as the plain appearance of that capacity. Skill is the thing that one knows. Execution is the thing that one does.

5. Open ability is relative, not total, and relies on upon the collaboration of every last one of the participants.

Grammatical or Linguistic Competence: In a more extensive sense, the term alludes to the syntactically suitable use of the semantic structures of the dialect. For speakers of a dialect.

Sociolinguistic Competence: This term relates to the learner's capacity to utilize the dialect legitimately as a part of diverse social settings. Sociolinguistic ability therefore shows the learners' learning of going past the strict significance of expressions.

Discourse Competence: This fitness bargains principally with the capacity to arrange the thoughts in a reasonable and easily streaming approach to guarantee solidarity in importance.

Strategic Competence: Key Competence alludes to the learners' capacity to gain verbal and non-verbal correspondence procedures. The methodologies are the methods by which learners manage potential breakdowns in correspondence. (Beltrán-Palanques, 2014: 59-70).

This hypothetical model of informative ability has experienced some further alterations over the long haul. Bortoluzzi, (2014) has proposed a more perplexing model of informative skill, which he calls "Dialect Competence." Bachman's model of dialect fitness is illustrated in Figure 4.1

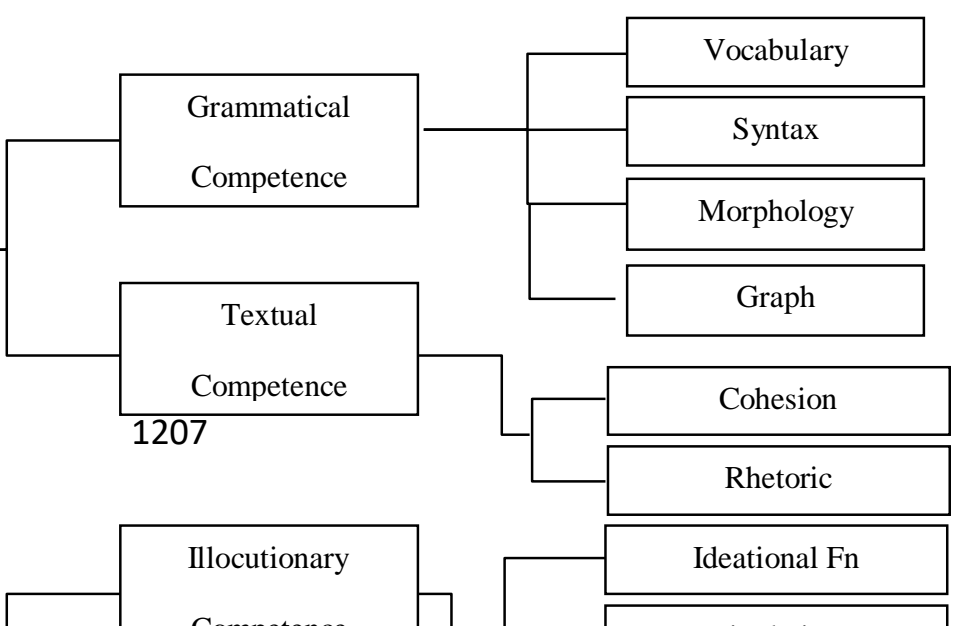


Figure 4.1: Components of Language Competence (Ozsevik, 2010)

Sociolinguistic ability as characterized by Celce-Murcia and Dornyei (1995) was separated into two different sober minded classifications, to be specific illocutionary capability and sociolinguistic fitness. Illocutionary capability was to do with the utilitarian parts of dialect. By sociolinguistic skill. He additionally attaches vital fitness as a totally separate component of informative dialect capacity, which basically serves an official capacity of settling on a definite conclusion.

\subsection{Communication in the Language Classroom}

In the perfect CLT classroom, the educator directs the students to utilize the dialect for genuine correspondence purposes. On the off chance that the teacher is doing the majority of the talking, the students are not figuring out how to talk. The educator needs to be the 'Wise on the stage' for generally yet the students need to contribute as well. The 'wise on the stage' is helpful for exhibiting new data, presenting and exploring sentence structure structures, general classroom administration, etc. Then again, the wise on the stage' ought 


\section{QALAAI ZANISTSCIENTIFIC JOURNAL \\ A Scientific Quarterly Refereed Journal Issued by Lebanese French University - Erbil, Kurdistan, Iraq \\ Vol. (5), No (2), Spring 2020 \\ ISSN 2518-6566 (Online) - ISSN 2518-6558 (Print)}

to lead the students towards genuine correspondence movement where the students are taking an interest in informative acts.

\subsection{Summary}

Students that are propelled to learn anything but difficult for them to show it. They are more inclined to listen to the educator and to add to the classroom group. Exercises and materials ought to be intriguing and applicable. Students ought to be urged to speak and expound on subjects and encounters that are intriguing and pertinent to them.

The targets of Communicative Language Teaching:

- Students will figure out how to utilize dialect as a method for representation

- Students will utilize dialect as a method for communicating qualities and judgments

The utilization of genuine materials is empowered in the CLT classroom. Course books can serve as a manual for the vocabulary and structures that need to be adapted as a base standard. Nonetheless, classes get to be substantially more fascinating through incorporating books, magazines, daily papers, film tickets, items/item names, website pages, interactive media, DVDs, leaflets and considerably more.

\section{Conclusion}

The deniability of English language being the language of wilder communication will be an error which should be corrected knowing the fact that English language has become a universal language. In so many former British colonies, especially in West Africa, English language has become their official language or lingua Franca. This study has therefore been able to examine so many critical problems facing some students in Kurdistan, the cause of the problems and solutions to those problems.

Based on the interview conducted and practical investigations made, it is clearly obvious that the problem in English proficiency in Kurdistan's classrooms is based on the limited time given to teaching English language in the classrooms, some teachers teaching students to pass exam not to make it as a language of communication, not using CLT approach in the class, lack of academic resources 


\section{QALAAI ZANISTSCIENTIFIC JOURNAL \\ A Scientific Quarterly Refereed Journal Issued by Lebanese French University - Erbil, Kurdistan, Iraq Vol. (5), No (2), Spring 2020 \\ ISSN 2518-6566 (Online) - ISSN 2518-6558 (Print)}

and laboratory for English pronunciation. Also, some students are learning for passing exam only, and deficiency of some of the English teachers in classrooms and lack of training for the English etc. These problems persist because the government has not implemented a law that makes English language a second or official language. The research arrives to a logical conclusion that English language can only be made effective in classrooms of Kurdistan if the students and teachers take it as a language of communication not as a subject which is meant to be passed in exam or taking it as a foreign language.

\section{REFERENCES:}

Ahmad, S., and Rao, C. (2013). Applying Communicative Approach in Teaching English as a Foreign Language: a Case Study of Pakistan. Institute of International \& Comparative Education, Northeast Normal University, China. ISSN: 1697-7467.pp 187-203.

Ansarey, D. (2012). Communicative Language Teaching in EFL Contexts: Teachers Attitude and Perception in Bangladesh. ASA University Review, Vol. 6 No. 1.Department of English, ASA University Bangladesh.

Bax, S. (2003).The end of CLT: a context approach to language teaching. ELT Journal Volume 57/3.Oxford University Press.

Beltrán-Palanques, V. (2014). Fostering Intercultural Communicative Competence in the Foreign Language Classroom: Pedagogical Implications. International Journal of English Language \& Translation Studies. 2(2), 59-70 Retrieved from http://www.eltsjournal.org.

Celce-Murcia, M., and Dornyei, Z. (1995). Communicative Competence: A Pedagogically Motivated Model with Content Specifications. University of California, Los Angeles. Issues in Applied Linguistics. ISSN 1050-4273.pp 5-35. Dahmardeh, M. (2009). Communicative Textbooks: English Language Textbooks in Iranian Secondary School. Linguistic online 40, 4/09.

Doman, E.; Robertson, P.; Dash, P., and Jung, J. (2005). The EFL Professional's Written Forum. Asian EFL Journal Press A Division of Time Taylor International Ltd. Trustnet Chambers. P.O. Box 3444. Road Town, Tort ol a. British Virgin Islands. ISSN. 1738-1460. 


\section{QALAAI ZANISTSCIENTIFIC JOURNAL \\ A Scientific Quarterly Refereed Journal Issued by Lebanese French University - Erbil, Kurdistan, Iraq \\ Vol. (5), No (2), Spring 2020 \\ ISSN 2518-6566 (Online) - ISSN 2518-6558 (Print)}

Halliday, M., A., K. (1993). Towards a Language-Based Theory ofLearning.5 Laing Avenue, Killara, New South Wales, Australia 2071.Linguistics and Education 5, pp. 93- 116.

Karim, Kh, M., R. (2004). Teachers' perceptions, attitudes and expectations about Communicative Language Teaching (CLT) in post-secondary education Bangladesh. Department of Curriculum and Instruction University of Victoria. A Thesis Submitted in Partial Fulfillments of the Requirements for the Degree of MASTERS OF ARTS.

Kelly, M. (2011). Seven hundred reasons for studying languages. www.llas.ac.uk/700reasons. Linguistics and Area Studies.

Keskin, Y. (2014). US Influence On The Education System InTurkey: An Analysis Of Reports By American Education Specialists. Sakarya University, Turkey. Journal of International Education Research - Third Quarter. Volume 10, Number 3.

Mullen, C., A.; Greenlee, B., J., \& Bruner, D., Y. (2005). Exploring the TheoryPractice Relationship in Educational Leadership Curriculum Though Metaphor. International Journal of Teaching and Learning in Higher Education, Volume 17, Number 1, 1-14.http://www.isetl.org/ijtlhe/. ISSN 1812-9129.

NEA, (2007). The Benefits of Second Language Study. Research Findings with Citations.Regarding World Language Education.

Ozsevik, Z. (2010). The Use of Communicative Language Teaching (CLT): Turkish EFL Teachers' Perceived Difficulties in Implementing CLT in Turkey. Submitted in partial fulfillment of the requirements for the degree of Master of Arts in Teaching of English as a Second Language in the Graduate College of the University of Illinois at Urbana-Champaign.

Paradis, J., Kirova, A., \&Dachyshyn, D., M. (2005). Working with Young Children who are Learning English as a New Language. Alberta Education Cataloguing in Publication Data. Alberta Education. Early Learning Branch. ISBN 978-0-77858146-8.online:

http://education.alberta.ca/teachers/program/esl/resources.aspx.

SAVIGNON, S., J., and WANG, Ch. (2003). Communicative language teaching in EFL contexts: Learner attitudes and perceptions. IRAL 41, 223-249 0019042X/2003/041-0223 C_Walter de Gruyter.

Vongxay, H. (2013). The Implementation of Communicative Language Teaching (CLT) In an English Department in a Lao Higher Education all Institution: A Case 
Study. A thesis submitted in partial fulfillment of the requirements for the degree of Master of Education Unitec Institution of Technology, New Zealand.

Wiriyachitra, A. (2006). English Language Teaching and Learning in Thailand in this Decade. Thai TESOL.

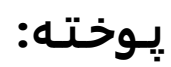

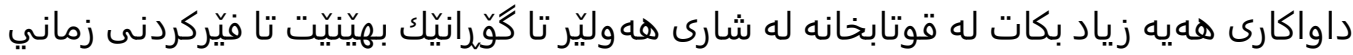

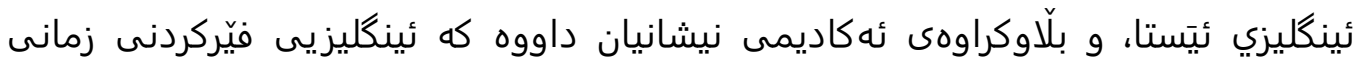

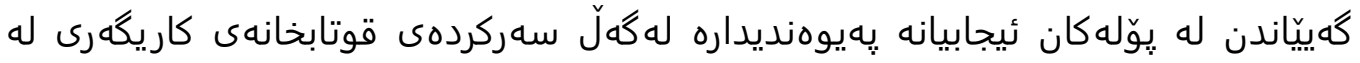

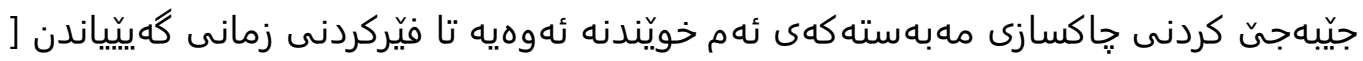

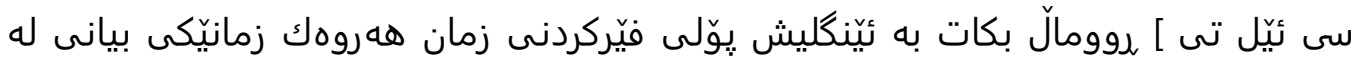

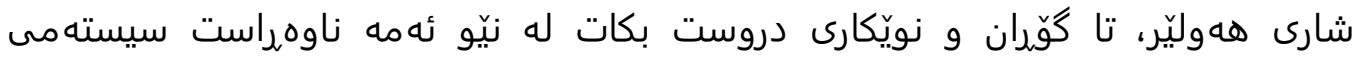

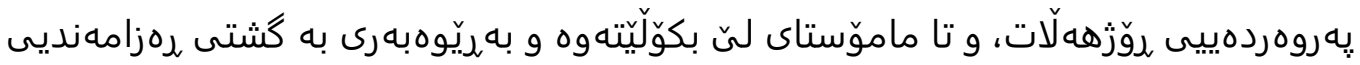

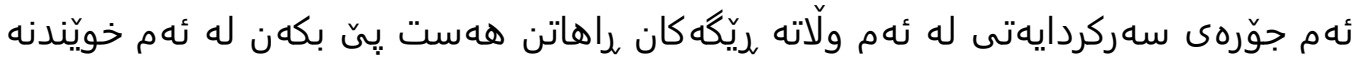

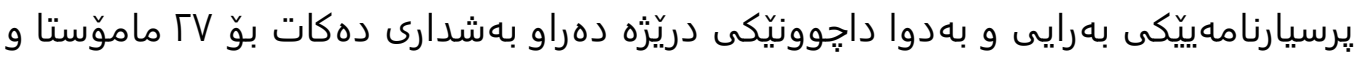

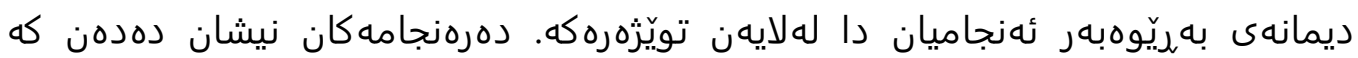

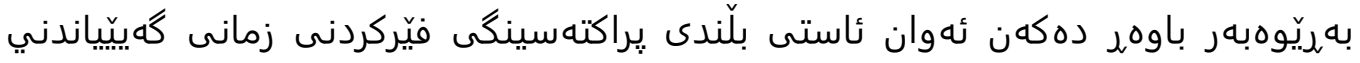

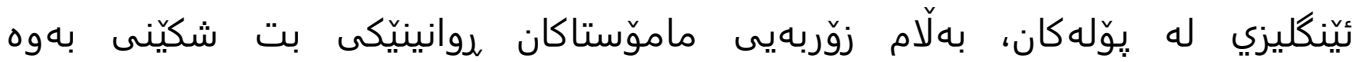

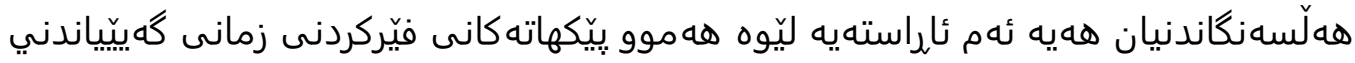

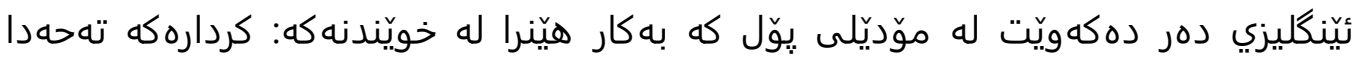

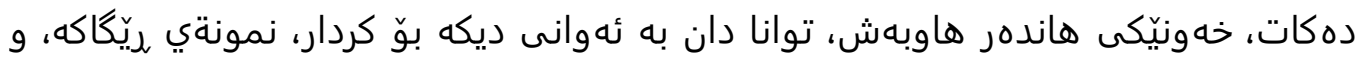

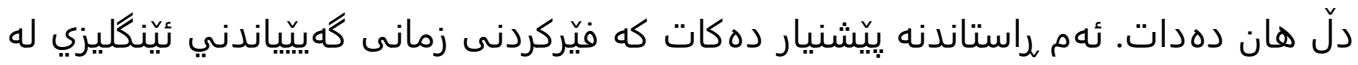

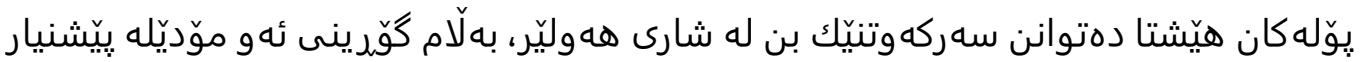
دهريّت. 


\section{QALAAI ZANISTSCIENTIFIC JOURNAL}

A Scientific Quarterly Refereed Journal Issued by Lebanese French University - Erbil, Kurdistan, Iraq

Vol. (5), No (2), Spring 2020

ISSN 2518-6566 (Online) - ISSN 2518-6558 (Print)

\section{وجهة نظر مدرسي اللغة الإنجليزية كلغة أجنبية حول استخدام اللغة الإنجليزية في تدريس اللغة الإنجليزية في فصول اللغة الإنجليزية في النية مدينة أربية الربيل}

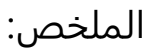

هناك طلب متزايد في المدارس بمدينة أربيل لإحداث تغيير في تعاليم ELT الحالية

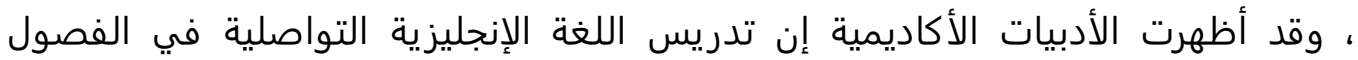

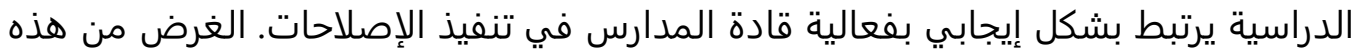

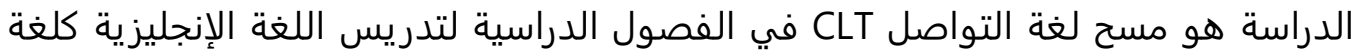

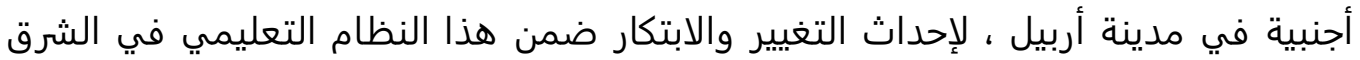

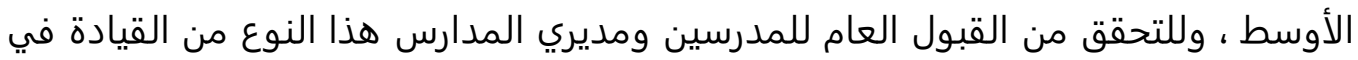

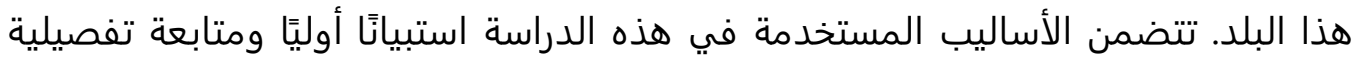

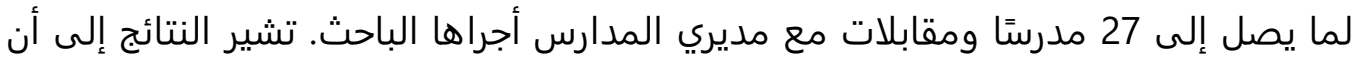

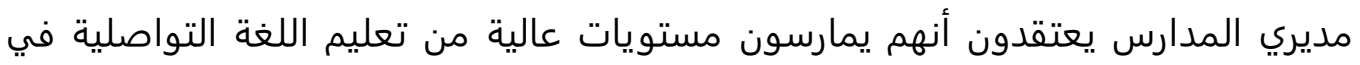

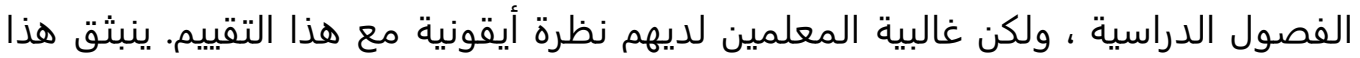

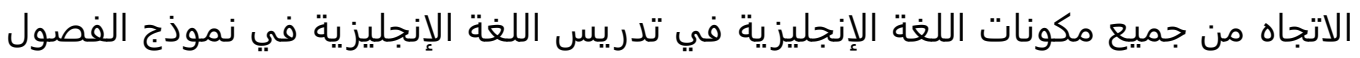

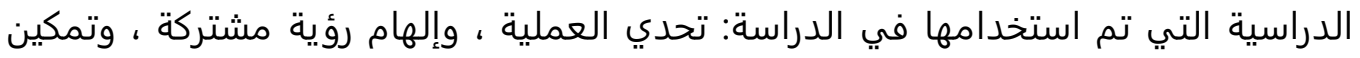

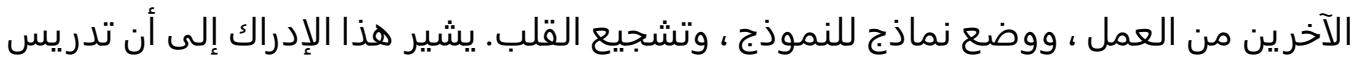

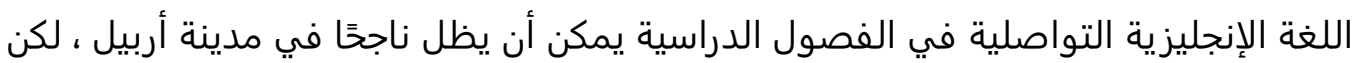
يُقترح تعديل هذا النموذج. 